\title{
MAJOR, TRACE ELEMENT AND SR-ISOTOPE CHARACTERIZATION OF THE SAMOTHRAKI \\ TERTIARY VOLCANIC ROCKS, NE AEGEAN
}

\author{
M. VLAHOU ${ }^{1}$, G. CHRISTOFIDES ${ }^{1}$, G. ELEFTHERIADIS ${ }^{1}$, L. PINARELLI' ${ }^{2}$, A. KASSOLI-FOURNARAKI ${ }^{1}$
}

\section{ABSTRACT}

Tertiary volcanic rocks of the Samothraki Island were found to show a wide range of composition. Two series have been distinguished showing diverging trends both in major and in trace element diagrams. Sr-isotope data show even more pronounced grouping of the two series thus reinforcing the suggestion of diverse evolutionary processes. A possible origin from either an enriched mantle source for the old volcanic series and mantle plus crust for the young volcanic rock series is suggested. Fractional crystallization or any other closed system process cannot account for the geochemical and isotopic variations seen witin the rock series. More complex processes must be responsible for their evolution history.

KEY WORDS: North Aegean Sea, Samothraki, volcanics, petrology, geochemistry, Sr-isotope, geochronology.

\section{INTRODUCTION}

Samothraki is an island in the northeast Aegean Sea (Fig. 1) where Tertiary volcanic rocks outcrop. These rocks are considered to belong to the widespread volcanic activity that affected the broader area of the north Aegean Sea including the on-shore areas. It started during the Eocene in the Bulgarian part of the Rhodope Massif and progressively migrated southwards to the central Aegean Sea and western Anatolia, where it died out in the Middle Miocene (Fyticas et al. 1985, Eleftheriadis and Lippolt 1984).

Petrological, geochemical and mineralogical studies on the Samothraki volcanic rocks have been presented by previous workers (Eleftheriadis et al. 1989, 1993) as well as K-Ar geochronology on limited number of samples (Eleftheriadis et al. 1994). New major, trace element and $\mathrm{Sr}$ isotope data, as well as Rb-Sr biotite ages are presented in this paper, aiming at contributing to the clarification of the origin and evolution of the Samothraki volcanic rocks. This paper is part of the $\mathrm{PhD}$ thesis of the first author.

\section{GEOLOGY}

The Island of Samothraki belongs geotectonically to the Circum-Rhodope belt (Kauffman et al. 1976). Five units have been distinguished after lithological studies of the area; the basement, the ophiolitic unit, the clastic series, the Tertiary igneous rocks and the Neogene to Quaternary sedimentary unit.

The basement is comprised of low grade metamorphic rocks - argillaceous and quartzose slates, schistose greywackes and marbles - of Mesozoic age (Davis 1963, Heiman 1967). It is partly intruded by the Upper Jurassic ophiolitic unit (Tsikouras et al. 1990) that consists of gabbros, diorites, diabases, and basalts. The whole unit is cut by doleritic dykes and has undergone metamorphic and cataclastic processes (Tsikouras 1992). Middle to Upper Eocene clastic neritic sequence and nummulitic limestones overlay discordantly the ophiolites. Intercalations of pyroclastic materials were found in these sedimentary rocks (Heimann et al. 1972).

The unit of the Tertiary igneous rocks comprises two intrusions of the "Samothraki granite" and the Tertiary volcanic rocks that cover the lower north-east, west and south-west slopes of the island. The granite is a normally zoned high-K calc-alkaline metaluminous to slightly peraluminous intrusion of Miocene age (Kyriakopoulos 1987, Christofides et al. 1990, 2000). The volcanic rocks form mainly domes, dykes, and lava flows that are seen to intrude and in some cases overlie the ophiolites and the clastic neritic series.

The stratigraphy of Samothraki is completed by the Neogene and Quaternary sedimetary rocks that cover most of the periphery of the island. 




Fig. 1. Schematic geological map of the Samothraki island. 1 = Tertiary-Quaternary sedimentary rocks, $2=$ Young Volcanic Rock Series, 3 = Old Volcanic Rock Series, 4-6 = Granitic complex, 7 = Gabbrodiotire, $8=$ Ophiolites, 9 = Basement rocks.

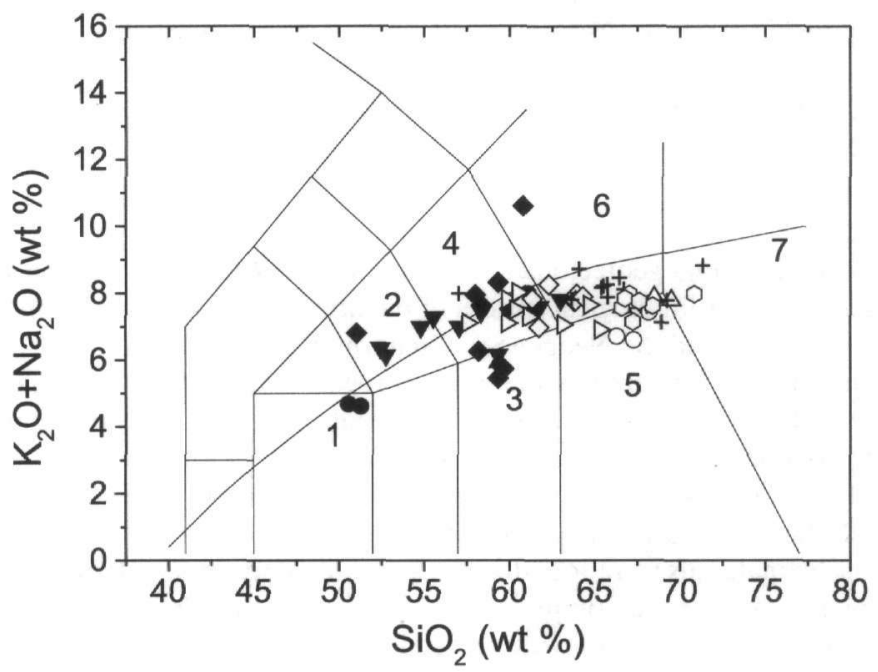

Fig. 2. Classification of the anhydrous normalized volcanic rocks of Samothraki Island after Le Maitre et al. (1989). Open symbols $=$ YVRS, Closed symbols $=$ OVRS. Circle $=$ Hora, Triangle $=$ Brehos, Diamond $=$

Tourli, Cross $=$ Lakoma, Tilted triangle $=$ Ag. Paraskevi, Hexagon $=$ Alonia $.1=$ Basalt, $2=$ Basaltic trachyande-site, $3=$ Andesite, $4=$ Trachy-andesite, $5=$ Dacite, $6=$ Trachyte, $7=$ Rhyolite. 
Table 1. Major (wt\%) and trace element (ppm) values of representative samples from the Samothraki volcanic rocks.

\begin{tabular}{|c|c|c|c|c|c|c|c|c|c|c|c|}
\hline & $\begin{array}{l}\text { X-8 } \\
\text { B-O }\end{array}$ & $\begin{array}{r}\text { MBR-103 } \\
\text { A-0 }\end{array}$ & $\begin{array}{r}\text { MT-125 } \\
\text { TRAN-O }\end{array}$ & $\begin{array}{r}\text { MX-110 } \\
\text { TRAN-O }\end{array}$ & $\begin{array}{c}\text { MT-118 } \\
\text { TRA-Y }\end{array}$ & $\begin{array}{r}\text { MAGP-110 } \\
\text { HKD-Y }\end{array}$ & $\begin{array}{r}\text { MAL-111 } \\
\text { HKD-Y }\end{array}$ & $\begin{array}{r}\text { MLK-109 } \\
\text { TRA-Y }\end{array}$ & $\begin{array}{r}\text { MBR-101 } \\
\text { HKD-Y }\end{array}$ & $\begin{array}{c}\text { MX-113 } \\
\text { HKD-Y }\end{array}$ & $\begin{array}{r}\text { LK-10 } \\
\text { R-Y }\end{array}$ \\
\hline $\mathrm{SiO}_{2}$ & 51.28 & 56.07 & 59.15 & 61.01 & 63.18 & 65.06 & 63.64 & 65.65 & 68.88 & 67.72 & 70.89 \\
\hline $\mathrm{TiO}_{2}$ & 1.40 & 0.57 & 0.71 & 0.71 & 0.75 & 0.40 & 0.58 & 0.51 & 0.35 & 0.39 & 0.76 \\
\hline $\mathrm{Al}_{2} \mathrm{O}_{3}$ & 16.89 & 13.90 & 17.52 & 16.64 & 14.77 & 15.58 & 15.77 & 14.99 & 15.11 & 15.01 & 13.32 \\
\hline $\mathrm{Fe}_{2} \mathrm{O}_{3}$ & 7.20 & 4.20 & 5.36 & 3.85 & 2.92 & 2.23 & 2.60 & 2.98 & 2.25 & 2.01 & 1.48 \\
\hline $\mathrm{FeO}$ & 2.65 & 1.65 & 0.88 & 1.85 & 1.33 & 0.73 & 1.52 & 0.67 & 0.62 & 0.98 & 0.33 \\
\hline $\mathrm{MnO}$ & 0.22 & 0.10 & 0.13 & 0.15 & 0.10 & 0.09 & 0.09 & 0.08 & 0.06 & 0.07 & 0.07 \\
\hline $\mathrm{MgO}$ & 4.00 & 4.60 & 1.06 & 2.31 & 3.53 & 1.66 & 4.19 & 1.88 & 1.78 & 2.00 & 1.19 \\
\hline $\mathrm{CaO}$ & 11.44 & 7.58 & 6.09 & 5.02 & 3.63 & 3.81 & 2.00 & 3.20 & 2.32 & 3.04 & 1.82 \\
\hline $\mathrm{Na}_{2} \mathrm{O}$ & 4.11 & 2.81 & 3.82 & 3.93 & 3.04 & 3.35 & 3.36 & 3.61 & 4.17 & 4.10 & 3.15 \\
\hline $\mathrm{K}_{2} \mathrm{O}$ & 0.50 & 2.79 & 3.59 & 3.59 & 4.83 & 3.56 & 4.16 & 4.37 & 3.55 & 3.54 & 5.62 \\
\hline $\mathrm{P}_{2} \mathrm{O}_{5}$ & 0.31 & 0.12 & 0.26 & 0.23 & 0.72 & 0.26 & 0.48 & 0.47 & 0.22 & 0.24 & 0.76 \\
\hline \multirow[t]{2}{*}{ LOI } & - & 5.61 & 1.44 & 0.72 & 1.21 & 3.28 & 1.61 & 1.61 & 0.90 & 0.88 & 0.63 \\
\hline & 100.00 & 100.00 & 100.01 & 100.01 & 100.01 & 100.01 & 100.00 & 100.02 & 100.21 & 99.98 & 100.02 \\
\hline $\mathrm{Rb}$ & 14 & 105 & 131 & 148 & 162 & 160 & 149 & 167 & 170 & 166 & 267 \\
\hline $\mathrm{Sr}$ & 882 & 723 & 464 & 669 & 859 & 773 & 800 & 1332 & 826 & 914 & 1036 \\
\hline $\mathrm{Ba}$ & 300 & 528 & 656 & 759 & 2079 & 1471 & 2458 & 2408 & 1278 & 1439 & 2164 \\
\hline $\mathrm{Cr}$ & 23 & 243 & $<3$ & 37 & 8 & 3 & 15 & 8 & 6 & 12 & 71 \\
\hline $\mathrm{Ni}$ & 7 & 50 & $<3$ & 10 & 9 & 3 & 5 & 4 & 3 & 3 & 29 \\
\hline $\mathrm{Zn}$ & 88 & 51 & 75 & 57 & 74 & 52 & 58 & 56 & 41 & 47 & 39 \\
\hline V & 247 & 150 & 134 & 190 & 103 & 77 & 79 & 99 & 68 & 77 & 81 \\
\hline $\mathrm{Nb}$ & 3 & 6 & 7 & 10 & 18 & 14 & 14 & 17 & 12 & 13 & 17 \\
\hline $\mathrm{Zr}$ & 197 & 142 & 195 & 199 & 462 & 238 & 319 & 315 & 211 & 229 & 388 \\
\hline $\mathrm{Y}$ & 32 & - & 24 & 18 & 13 & - & - & - & 9 & - & 16 \\
\hline Co & 53 & 23 & 16 & 20 & 13 & 5 & 9 & 7 & 7 & 6 & 24 \\
\hline $\mathrm{Pb}$ & 11 & 24 & 22 & 21 & 32 & 62 & 64 & 82 & 32 & 61 & 47 \\
\hline Th & - & 17.00 & 17 & 22 & 24 & 4.00 & 36.00 & 31.00 & 24 & 20.00 & 96 \\
\hline $\mathrm{U}$ & 1.24 & 6.35 & 3.26 & 4.31 & 3.97 & 12.17 & 8.42 & 12.64 & 5.06 & 9.94 & 5.5 \\
\hline $\mathrm{La}$ & 19 & 28.57 & 31 & 32 & 68 & 65.59 & 75.19 & 104.26 & 51 & 75.00 & 68 \\
\hline $\mathrm{Ce}$ & 51 & 52.06 & 67 & 68 & 137 & 111.35 & 134.24 & 185.42 & 100 & 132.91 & 144 \\
\hline Pr & - & 6.06 & - & & - & 11.09 & 14.11 & 21.35 & - & 14.60 & \\
\hline Nd & 27.7 & 22.73 & 29.4 & 27.7 & 53.3 & 39.30 & 51.58 & 69.84 & 34.4 & 49.45 & 58.5 \\
\hline Sm & 6.73 & 4.02 & 6 & 5.51 & 8.46 & 5.20 & 7.61 & 9.68 & 5.48 & 6.64 & 9.19 \\
\hline $\mathrm{Eu}$ & 1.83 & 1.01 & 1.51 & 1.17 & 1.98 & 1.66 & 2.12 & 2.9 & 1.22 & 1.74 & 2.01 \\
\hline Gd & 6.39 & 4.42 & 5.37 & 4.85 & 6.99 & 8.31 & 10.28 & 12.9 & 4.72 & 8.3 & 7.16 \\
\hline $\mathrm{Tb}$ & 0.79 & 0.27 & 0.59 & 0.49 & 0.59 & 0.31 & 0.35 & 0.7 & 0.36 & 0.45 & 0.59 \\
\hline Dy & 4.97 & 2.95 & 3.74 & 2.97 & 3.23 & 2.50 & 3.49 & 3.9 & 1.98 & 2.56 & 3.11 \\
\hline Ho & 0.84 & 0.36 & 0.61 & 0.45 & 0.41 & 0.28 & 0.25 & 0.38 & 0.25 & 0.23 & 0.4 \\
\hline $\mathrm{Er}$ & 2.58 & 1.46 & 1.98 & 1.41 & 1.22 & 1.33 & 1.22 & 1.47 & 0.82 & 0.90 & 1.24 \\
\hline $\mathrm{Tm}$ & 0.33 & n.d & 0.25 & 0.17 & 0.12 & n.d & n.d & n.d & 0.08 & n.d & 0.13 \\
\hline $\mathrm{Yb}$ & 2.55 & 1.28 & 2.12 & 1.47 & 1.01 & 1.21 & 1.07 & 1.19 & 0.76 & 0.90 & 1.1 \\
\hline Lu & 0.31 & n.d & 0.27 & 0.17 & 0.11 & n.d & n.d & n.d & 0.08 & n.d & 0.12 \\
\hline Hf & - & 1.06 & - & & - & n.d & 4.41 & 0.93 & - & n.d & \\
\hline $\mathrm{Ta}$ & - & 0.26 & - & & - & 5.15 & 0.87 & 0.99 & - & 4.62 & \\
\hline
\end{tabular}

- = not analyzed, n.d. $=$ non detected, $B=$ basalt, $A=$ andesite, $T R A N=$ trachyandesite, $T R A=$ trachyte, $H K D=$ high $-K$ dacite, $R=$ rhyolite, $O=O V R S, Y=$ YVRS.

\section{ANALYTICAL METHODS}

Major and trace elements $(\mathrm{Rb}-\mathrm{Zr}$, Table 1$)$ were analyzed by XRF at the Department of Earth Science of the University of Florence by XRF fluorescence. Additional trace elements as well as REE analyses were carried out at the University of Bristol by ICP-MS. Sr isotope analyses on whole rock samples as well as biotite 

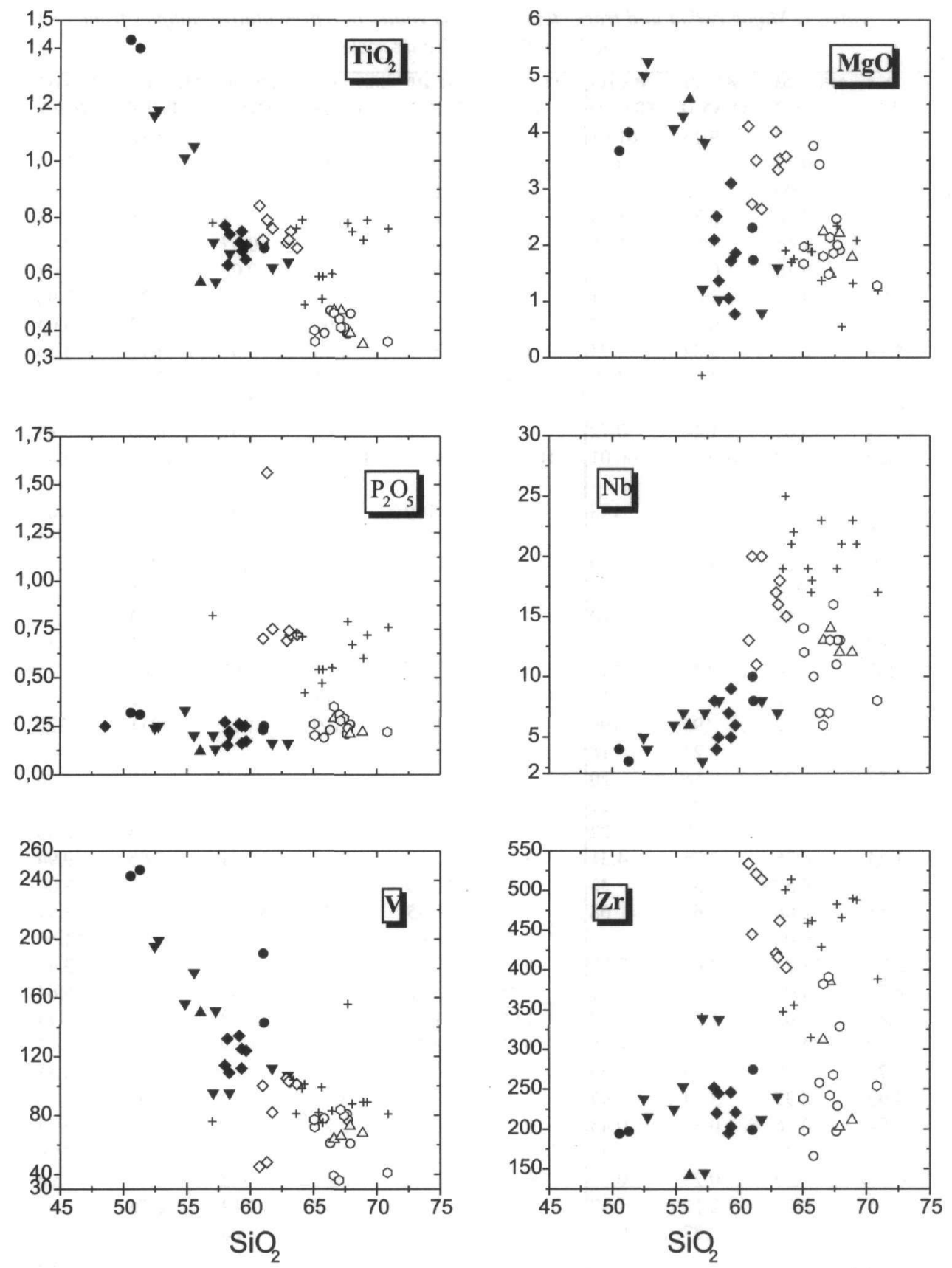

Fig. 3. Variation diagrams for selected major and trace elements of the Samothraki volcanic rocks.

Symbols as in Fig. 2.

separates were carried out at the "Istituto di geocronologia e geochimica isotopica", CNR Pisa. Sr isotope ratios were acquired with a multicollector Finnigan MAT 262 mass spectrometer. Rb and Sr concentrations were determined by isotope dilution. Quoted errors are at the $95 \%$ confidence level.

\section{PETROGRAPHY}

The volcanic rocks of Samothraki show a wide compositional range. Previous researches (Eleftheriadis et al. 
1989, 1993) have divided these rocks, on the basis of stratigraphic and geochemical criteria, into two series. The Old Volcanic Rock Series (OVRS) is of calc-alkaline to shoshonitic affinity and Oligocene in age. The Young Volcanic Rock Series (YVRS) is of Miocene age and of high-K calc-alkaline to shoshonitic affinity (Eleftheriadis et al. 1994).

The OVRS consists of basalts, basaltic trachyandesites, andesites and trachyandesites (Fig. 2). The rocks mainly occur as lava flows which are sometimes intercalated with a volcaniclastic series that also hosts some products of this volcanic series. Some sills also occur interbedded in the above volcaniclastic series. Macroscopically they are dark in colour with a slight porphyritic to subaphyric texture. They consist mainly of basic plagioclase $\left(A n_{70}-A n_{45}\right)$ and pyroxene. In some cases fully altered biotite and hornblende were found. Kaolin, serpentine, zeolites, carbonate minerals and oxides in various ratios were also identified.

The YVRS consists of rhyolites, latites, trachytes and dacites (or high-K dacites as may be qualified in accord with the concept developed by Peccerillo and Taylor, 1976) (Fig 2). Field evidence show that they mainly form lava domes intruding the OVRS as well as the volcaniclastic series mentioned above. They are in general lighter in colour than the OVRS and are characterized by the presence of idiomorphic phenocrysts of K-feldspar, which can reach $10 \mathrm{~cm}$ in length. Other minerals that were identified are quartz, plagioclase and biotite. Hornblende is found in great amounts but not in all areas/domes, while small amounts of pyroxene were also noted.

\section{GEOCHEMISTRY}

Geochemical grouping between the two series can be identified in most variation diagrams. $\mathrm{MgO}, \mathrm{Ti}_{2} \mathrm{O}$ (Fig. 3) and $\mathrm{FeO}$ (not shown) show negative correlation with silica in both series although the slope and intercept are different. V (Fig. 3), Co, Cu, Zn, Y (not shown) show similar variations. $\mathrm{P}_{2} \mathrm{O}_{5}$ (Fig. 3) also show grouping although no trend is evident in either series. However, diverse correlation is evident in some trace element variation diagrams like $\mathrm{Nb}, \mathrm{Zr}, \mathrm{Ba}$.

REE abundances are also higher in YVRS than OVRS; SREE ranges from 201 to 414 in the former and from 125 to 238 in the latter group. The chondrite - normalized REE patterns (Fig. 4) are tightly banded in each series. However, LREE to HREE fractionation is distinctly higher in the young compared to the old series where HREE patterns are relatively flat. $(\mathrm{La} / \mathrm{Sm})_{\mathrm{N}}$ ranges from 1,7 to 5,8 with an average value of 3,6 for the OVRS and from 4,6 to 7,8 with an average value of 6,0 for the YVRS. $(\mathrm{Gd} / \mathrm{Yb})_{\mathrm{N}}$ ranges from 1,9 to 7,7 with an average of 3,3 for the OVRS and a respective range of 4,4 to 9,5 with an average of 6,8 for the YVRS. Eu anomaly is distinctly negative in both series implying that crystallization of feldspar was important in the evolution of both series.

The higher content of incompatible elements in the YVRS is also shown in figure 5 where the MORBnormalised spiderdiagrams (Pearce 1982) of selected samples are presented. Both series have similar multi-

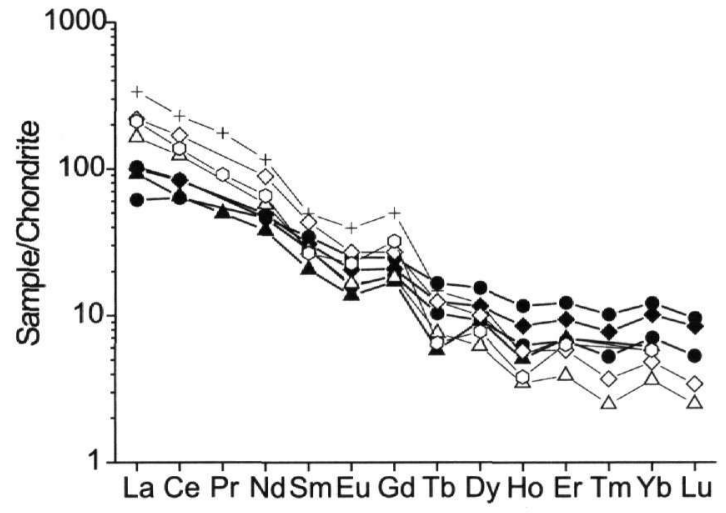

Fig. 4. Chondrite-normalised REE patterns. Normalization after Boynton (1984). Symbols as in Fig. 2.

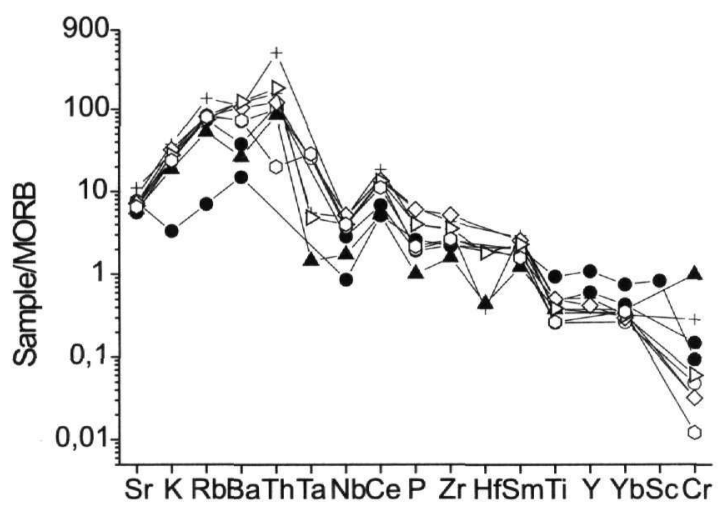

Fig. 5. MORB-normalized spiderdiagrams of incompatible elements of Samothraki volcanic rocks. Normalization after Pearce (1982). Symbols as in Fig. 2. 


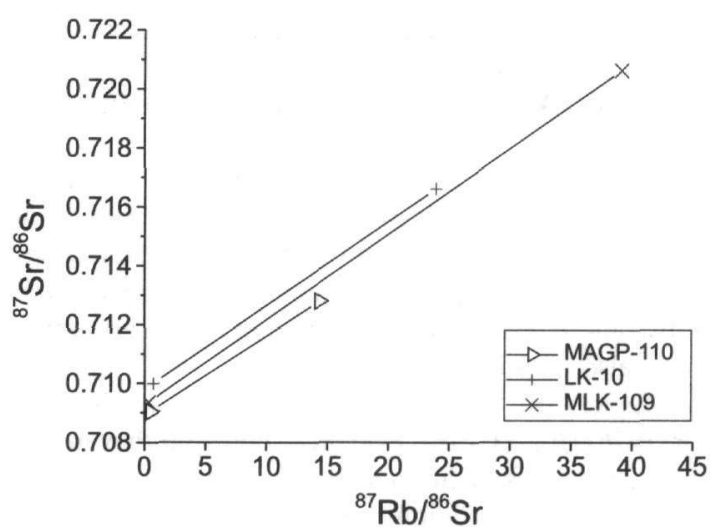

Fig. 6. Plot of ${ }^{87} \mathrm{Rb} /{ }^{86} \mathrm{Sr}$ vs ${ }^{87} \mathrm{Sr} /{ }^{86} \mathrm{Sr}$ (measured values) for whole rock - mineral pairs that yield isochrone ages.

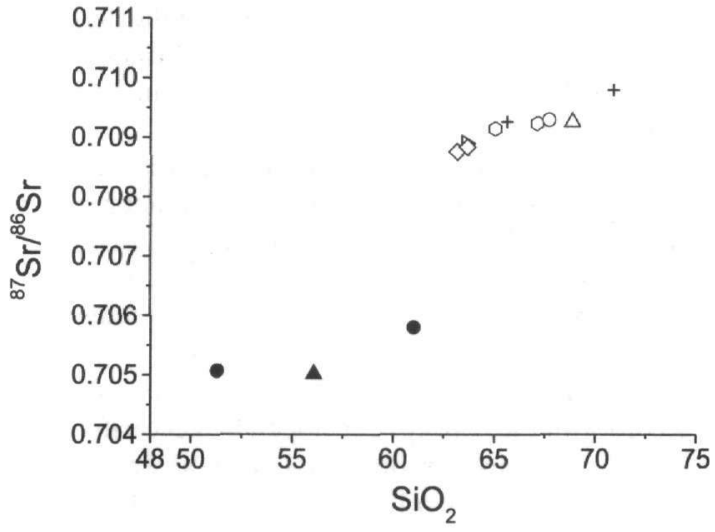

Fig. 7. Initial ${ }^{87} \mathrm{Sr} /{ }^{86} \mathrm{Sr}$ vs rock silica for analyzed samples from Samothraki island. Symbols as in fig. 2.

element profiles with strong enriched in LIL elements. They also show negative anomalies in $\mathrm{Nb}$ and $\mathrm{Ti}$ which is a characteristic feature of rocks from subduction related environments. Negative anomaly of $\mathrm{Ba}$ in respect to $\mathrm{Rb}$ and $\mathrm{Th}$ is also expressed by some samples. Similar anomaly is also shown by igneous rocks of the broader Rhodope Massif (Eleftheriadis 1995, Harkovska et al. 1998, Nedialkov \& Pe-Piper 1998, Yanev 1998). Harkovska et al. (1998) suggest that the prominent negative $\mathrm{Ba}, \mathrm{Sr}$ and $\mathrm{Eu}$ anomalies indicate feldspar fractionation.

\section{SR-ISOTOPE RATIOS}

In Table 2, Sr-isotope data for 11 samples is presented. Biotite separates from three samples of the YVR series, along with their respective whole rocks, were used to yield three independent $\mathrm{Rb}-\mathrm{Sr}$ isochron ages. $\mathrm{Rb} / \mathrm{Sr}$ biotite ages of the analyzed samples, reported in table 2 show small variation around the value of $20 \mathrm{Ma}$. This age is in agreement with data from Eleftheriadis et al. (1994), who dated the YVRS by K-Ar hornblende-rock method as Early Miocene (22,3 - 18,9 Ma). Regarding the OVRS, their mineral constituents, that are in most cases altered, did not allow to obtain $\mathrm{Rb} / \mathrm{Sr}$ mineral ages. However, K-Ar whole rock ages obtained by the above researchers, gave an average value of $25 \mathrm{Ma}$ (Eleftheriadis et al. 1994). Thus, initial Sr isotope ratios of YVRS and OVRS were calculated at 20 and $25 \mathrm{Ma}$, respectively. It must be emphasized here that the age difference between the two series is too small to affect the calculation of the initial Sr-isotopic ratio.

It is evident that the distinction between the two series is even more prominent in the isotopic data (Fig 7). The data obtained show significant coherence for each group. To be more specific the Sr initial isotopic ratio for the samples of the OVRS ranges between 0,70501 and 0,70581, whereas for the samples of the YVRS between 0,70876 and 0,70978 (Table 3). This data is similar to the initial $\mathrm{Sr}$ isotopic composition of collision related volcanic rocks in Eastern Rhodopes and Western Thrace (Yanev et al. 1998). In figure 7 a slight positive trend in the YVRS can be seen suggesting an open rather than a closed-system evolution.

\section{DISCUSSION}

It is evident from this study that the two volcanic series of Samothraki Island show distinct geochemical and isotopic characteristics. The OVRS show high $\mathrm{Ni}$ and $\mathrm{Cr}$ concentrations and high \# Mg. The low LREE to HREE fractionation is another evidence of their diversity. The initial Sr-isotopic ratio of 0,70501 to 0,70581 indicate that a mantle component took part in the petrogenesis of this series. The relatively high concentrations of LIL elements and the Sr-isotope values lead to the conclusion that an upper enriched mantle is most probably the source region of the old volcanic rock series of Samothraki.

YVRS on the other hand show higher silica content and higher concentration of incompatible elements than OVRS. They present higher LREE to HREE fractionation. The above together with their initial Sr-isotope values of 0,70876 to 0,70978 indicate the involvement of a crustal component in their origin. Mineralogical data indicate that this melt could be mixed or affected in some way by another, more mafic component, possibly of mantle origin.

Geochemical grouping of the samples both in the variation diagrams of the major and trace elements (Fig. 
Table 2. Sr-isotope ratio of Samothraki volcanic rocks and minerals. WR $=$ whole rock, Bi $=$ biotite, $\left({ }^{87} \mathrm{Sr} /{ }^{86} \mathrm{Sr}\right)_{m}$ $=$ measured values, $\left({ }^{87} \mathrm{Sr}{ }^{86} \mathrm{Sr}\right)_{i}=$ initial ratio.

\begin{tabular}{|c|c|c|c|c|c|c|c|c|}
\hline & Sample & $\begin{array}{l}\text { Mate } \\
\text { rial }\end{array}$ & ${ }^{87} \mathrm{Rb} /{ }^{86} \mathrm{SI}$ & $\left({ }^{87} \mathrm{Sr} / /^{86} \mathrm{Sr}\right)_{\mathrm{m}}+/-$ & $\overline{R b}$ & $\overline{S x}$ & $\left({ }^{87} \mathrm{Sr} /{ }^{86} \mathrm{Sr}\right)_{i}+/-$ & $\begin{array}{l}\text { Age } \\
\text { (Ma) }\end{array}$ \\
\hline \multirow{10}{*}{$\sum_{1-1}^{\infty}$} & MAGP-110 & WR & 0,49952 & 0,709035 & 150 & 870 & 0,70890 & \\
\hline & & $\mathrm{Bi}$ & 14,350 & 0,712788 & 406 & 82 & & 19 \\
\hline & LK-10 & WR & 0,71764 & 0,709987 & 271 & 1091 & 0,70978 & \\
\hline & & $\mathrm{Bi}$ & 23,896 & 0,716606 & 593 & 72 & & 20 \\
\hline & MLK-109 & WR & 0,33068 & 0,709353 & 175 & 1530 & 0,70926 & \\
\hline & & $\mathrm{Bi}$ & 39,168 & 0,720620 & 511 & 38 & & 20 \\
\hline & MT-118 & WR & 0,545 & $0,708906 \quad 10$ & 162 & 859 & 0,70876 & \\
\hline & MAL-111 & WR & 0,598 & $0,709312 \quad 11$ & 160 & 773 & 0,70915 & \\
\hline & MBR-101 & WR & 0,56339 & $0,709415 \quad 10$ & 172 & 880 & 0,70926 & \\
\hline & $\mathrm{MX}-113$ & WR & 0,49526 & $0,709426 \quad 10$ & 169 & 1005 & 0,70929 & \\
\hline \multirow{4}{*}{ 告 } & $\mathrm{MX}-110$ & WR & 0,57462 & 0,706008 & 143 & 719 & 0,70581 & \\
\hline & MT-125 & WR & 0,69335 & $0,705459 \quad 10$ & 116 & 485 & 0,70522 & \\
\hline & MBR-103 & WR & 0,37940 & $0,705140 \quad 12$ & 99 & 757 & 0,70501 & \\
\hline & $\mathrm{x}-8$ & WR & 0,047 & 0,705089 & 14 & 861 & 0,70507 & \\
\hline
\end{tabular}

3) and the Sr-isotope initial ratio vs silica diagram (Fig. 7) is in favour of different paths of evolution for the two series. The cross cutting REE patterns (Fig. 4) the compositional variations in many diagrams of figure 3 and the Sr-isotopic composition, all suggest that the tow series are not genetically related. The YVRS could not result from the OVRS not only by simple fractional crystallization but even by an open system evolution scheme. Geological observations and mineral chemistry indicate that both series may be influenced -at different degreesby AFC and/or MFC. This is in accordance with the alternative suggestion by Eleftheriadis et al. (1993) for the evolution of YVRS through magma mixing processes.

Latest studies in the broader area of the Rhodope massif show that during the Oligocene - Miocene the area was affected by an extensional stress field. Potassium-rich igneous activity is a common feature of post-collisional extension orogens (Pe Piper et al. 1998). Anomalies of multi-element MORB-normalised spiderdiagrams of the samples studied, are similar with those shown by igneous rocks from the broader area, of similar age (Harkovska et al. 1998, Nedialkov \& Pe-Piper 1998, Yanev 1998) and were attributed to an older subduction environment that affected the source material of those rocks. For the Samothraki igneous rocks Pe-Piper et al. (1998) proposed a lithospheric mantle source based on $\mathrm{Pb}$-isotope composition and trace element data. This is in accordance with our Sr-isotopic data for the OVRS. However further study is needed to determine the true origin and evolution of the YVRS.

\section{ACKNOLEDGEMENTS}

Isotopic analyses have been carried out by means of the facilities of CNR Pisa, "Instituto di geocronologia e geochimica isotopica". The trace element analyses were carried out with the support of the "Training and Mobility of Researchers" Program of the Dept. of Earth Science of the University of Bristol. Many thanks we also owe to the Geology Dept. of the University of Florence for all the help in obtaining our supplementary data and Dr Koroneos for his comments on this paper.

\section{REFERENCE}

BOYNTON W. V. (1984) Geochemistry of the rare earth elements: Meteorite studies. In: Rare earth element geochemistry, ed. Henderson P., Elsevier, 63-114.

CHRISTOFIDES G., ELEFTHERIADIS G., ESSON J. (1990) Preliminary results on the magmatic evolution of the island of Samothraki granite (N. Greece). Geol. Rhodop., 2, 213-226.

CHRISTOFIDES G., ELEFTHERIADIS G., ESSON J. SOLDATOS T., KORONEOS A., BROECKER M. (2000) The evolution of the Samothraki granitic pluton (N. Aegean sea, Greece): geochronology, chemical and isotopic constraints for AFC modeling. Proc. $3^{\text {rd }}$ Int. Conf. Geol. Eastern Mediter, eds. Panayides I., Xenophontos 
C. and Malpas J., Nicosia, Cyprus.

DAVIS E. (1963) Geological structure of Samothraki island. Annal. Geol. Pays Hell., 14, 133-188 (in greek).

ELEFTHERIADIS G. (1995) Petrogenesis of the oligocene volcanics from the central Rhodope massif (N. Greece).

Eur. J. Mineral., 7, 1169-1182.

ELEFTHERIADIS G. AND LIPPOLT H. J. (1984) Altersbestimmungen zum oligozaenen Vulkanismus der SuedRhodopen/Nord-Griechenland. N. Jb. Geol. Palaeont. Mh., 3, 179-191.

ELEFTHERIADIS G., ESSON J., SOLDATOS T., CHRISTOFIDES G. (1993) Magmatic evolution of the Tertiary volcanic rocks of Samothraki island (Thrace, N. Greece). In: Honnorary Publication A. Panagos, ?, ?.? Polytechnical School, Athens, 330-348.

ELEFTHERIADIS G., CHRISTOFIDES G., MAVROUDCHIEV B., NEDYALKOV R., ANDREEV A., HRISTOV L. (1989) Tertiary volcanics from the East Rhodopes in Greece and Bulgaria. Geol. Rhodop., I, 202-217, Kliment Ohridski University Press.

ELEFTHERIADIS G., PE-PIPER G., CHRISTOFIDES G., SOLDATOS T., ESSON J. (1994) K-Ar dating of the Samothraki volcanic rocks, Thrace, North-Eastern Aegean (Greece). Bull. Geol. Soc. Greece, 30/1, 205-212.

FYTICAS M., INNOCENTI F., MANETTI P., MAZZUOLI R., PECCERILLO A., VILLARI L. (1985) Tertiary to Quaternary evolution of volcanism in the Aegean region. In: The geological evolution of Eastern Mediteranean, Geological Society Publication No17, eds. J.E. Dixon and A.H.F. Robertson, Blackwell Scientific Publications, 687-699.

HARKOVSKA A., MARCHEV P., MARCHEV PH., PECSKAY Z. (1998) Paleogene magmatism in the central Rhodope area, Bulgaria - A review and new data. Acta Vulcan., 10(2), 199-216.

HEIMANN K. (1967) Uber das Alter praetertiarer Gesteine des Nordwestterls der Insel Samothraki (Griechenland). Proc. Acad. Athens, 42, 153-160.

HEIMANN K. O., LEBKUCHNER H., KRETZLER W. (1972) Geological map, Samothraki, 1:50,000, I.G.M.E., Athens.

KAUFFMAN G., KOCKEL F., MOLLAT H. (1976) Notes on the stratigraphic and paleogeographic position of the Svoula formation in the innermost zone of the Hellenides (Northern Greece). Bull. Soc. Geol. France, 18, 225-230.

KYRIAKOPOULOS G.(1987) Geochronological, geochemical, mineralogical study of tertiary plutonic rocks of the Rhodope Massif and their isotopic character. PhD Thesis, University of Athens (in greek).

LEMAITRE R.W., BATEMAN P., DUDEK A., KELLER J., LAMEYRE LE BAS M.J., SABINE P.A., SCHMID R., SORENSEN H., STRECKEISEN A., WOOLEY A.R., ZANETTIN B. (1989) A classification of igneous rocks and glossary of terms. Blackwell, Oxford.

NEDIALKOV R., PE-PIPER G. (1998) Petrology of the volcanism in the southeastern part of the MomchilgradArda volcanic region, southeastern Bulgaria. Acta Vulcan., 10(2), 243-253.

PEARCE J.A. (1982) Trace element characteristics of lavas from destructive plate boundaries. In "Andesites: orogenic andesites and related rocks", Thorpe, R.S. ed. Wiley, Chichester, 525-548.

PECCERILLO R., TAYLOR S.R. (1976) Geochemistry of Eocene calc-alkaline volcanic rocks from the Kastamonu area, northern Turkey. Contr. Miner. Petrol., 58, 63-81.

PE-PIPER G., CHRISTOFIDES G., ELEFTHERIADIS G. (1998) Lead and neodymium isotopic composition of Tertiary igneous rocks of northern Greece and their regional significance. Acta Vulcan., 10(2), 255-263.

TSIKOURAS V. (1992). The ophiolites of Samothraki island (N. Aegean Sea, Greece)- Investigation of the geological, petrological and geochemical characteristics of the ophiolites and of the associated, adjacent formations. $\mathrm{PhD}$. Thesis, University of Patras (in greek).

TSIKOURAS V., PE-PIPER G., HATZIPANAGIOTOU K. (1990). A new date for the ophiolite on the northeastern margin of the Vardar zone, Samothraki, Greece. N. Jb. Miner. Mh., 11, 521-527.

YANEV Y. (1998) Petrology of the Eastern Rhodopes paleogene acid volcanics, Bulgaria. Acta Vulcan., 10(2), 265-277.

YANEV Y., INNOCENTI F., MANETTI P., SERRI G. (1998) Upper Eocene-Oligocene collision related volcanism in Eastern Rhodopes (Bulgaria) - Western Thrace (Greece): petrogenetic affinity and geodynamic significance. Acta Vulcan., 10(2), 265-277. 